\title{
Effects of Wannachawee Recipe with Antipsoriatic Activity on Suppressing Inflammatory Cytokine Production in HaCaT Human Keratinocytes
}

\author{
Mingkwan Na Takuathung, ${ }^{1,2}$ Ariyaphong Wongnoppavich, ${ }^{3}$ Pornsiri Pitchakarn, \\ Ampai Panthong, ${ }^{2}$ Parirat Khonsung, ${ }^{2}$ Natthakarn Chiranthanut, ${ }^{2}$ \\ Noppamas Soonthornchareonnon, ${ }^{4}$ and Seewaboon Sireeratawong ${ }^{2}$ \\ ${ }^{1}$ Department of Pharmacology, Doctor of Philosophy Program in Pharmacology, Faculty of Medicine and Graduate School, \\ Chiang Mai University, Muang 50200, Thailand \\ ${ }^{2}$ Department of Pharmacology, Faculty of Medicine, Chiang Mai University, Muang, Chiang Mai 50200, Thailand \\ ${ }^{3}$ Department of Biochemistry, Faculty of Medicine, Chiang Mai University, Muang, Chiang Mai 50200, Thailand \\ ${ }^{4}$ Department of Pharmacognosy, Faculty of Pharmacy, Mahidol University, Rajathevi, Bangkok 10400, Thailand
}

Correspondence should be addressed to Seewaboon Sireeratawong; seewaboon@gmail.com

Received 28 April 2017; Accepted 17 July 2017; Published 16 August 2017

Academic Editor: Gorkem Kismali

Copyright (C) 2017 Mingkwan Na Takuathung et al. This is an open access article distributed under the Creative Commons Attribution License, which permits unrestricted use, distribution, and reproduction in any medium, provided the original work is properly cited.

\begin{abstract}
Psoriasis is a chronic inflammatory and immune-mediated skin disease. The pathogenesis involves T cells activation via the IL23/Th17 axis. Conventional treatments of psoriasis have adverse events influencing patients' adherence. Wannachawee Recipe (WCR) has been effectively used as Thai folk remedy for psoriasis patients; however, preclinical evidence defining how WCR works is still lacking. This study defined mechanisms for its antiproliferation and anti-inflammatory effects in HaCaT cells. The cytotoxicity and antiproliferation results from SRB and CCK- 8 assays showed that WCR inhibited the growth and viability of HaCaT cells in a concentration-dependent manner. The distribution of cell cycle phases determined by flow cytometry showed that WCR did not interrupt cell cycle progression. Interestingly, RT-qPCR revealed that WCR significantly decreased the mRNA expression of IL-1 $\beta$, IL-6, IL-8, IL-17A, IL-22, IL-23, and TNF- $\alpha$ but induced IL-10 expression in TNF- $\alpha$ - and IFN- $\gamma$-induced HaCaT cells. At the protein level determined by ELISA, WCR significantly reduced the secretion of IL-17A, IL-22, and IL-23. The WCR at low concentrations was proved to possess anti-inflammatory effect without cytotoxicity and it did not interfere with cell cycle of keratinocytes. This is the first study to provide convincing evidence that WCR is a potential candidate for development of effective psoriasis therapies.
\end{abstract}

\section{Introduction}

Psoriasis is a chronic immune-mediated skin disease manifesting as focal formation of inflamed and scaly plaques derived from excessive proliferation of keratinocytes [1]. Interleukin 23 (IL-23) and interleukin 17 (IL-17), which are cytokines belonging to a subset of T-helper 17 (Th 17), play a major role in pathogenesis of psoriasis [2]. IL-23 functions as a key cytokine for stimulating survival and expansion of Th17 cells [3]. After this stimulation, the downstream effector molecules of Th17 cells, including IL-17A, IL-22, TNF- $\alpha$, and IL- 6 are produced in response to certain stimuli $[2,4]$ and subsequently induce keratinocyte proliferation and other hallmark features of psoriasis [5].

Choice of psoriatic treatment depends on many factors such as severity of the disease and its impact on patient's life [6]. For mild psoriasis, corticosteroids, vitamin D3 analogues, and calcineurin inhibitors have been currently used as topical therapies. For severe psoriasis, phototherapy or conventional systemic agents including methotrexate, cyclosporine, acitretin, and, in some countries, fumaric acid esters are chosen depending on the patient's condition [7]. Recently, biological therapies, which are proteins or antibodies targeting specific inflammatory mediators and $\mathrm{T}$ cells, have been 
TABLE 1: Plants used in WCR.

\begin{tabular}{|c|c|c|c|c|c|}
\hline & Thai name & Scientific name & Family name & Part used & Original source \\
\hline 1 & Kha & Alpinia galanga (L.) Willd. & Zingiberaceae & Rhizomes & \multirow{4}{*}{$\begin{array}{c}\text { Chanthaburi } \\
\text { Province, } \\
\text { Thailand }\end{array}$} \\
\hline 2 & Khao Yen Tai & Smilax glabra Wall.ex Roxb. & Smilacaceae & Rhizomes & \\
\hline 3 & Khao Yen Nuea & Smilax corbularia Kunth. & Smilacaceae & Rhizomes & \\
\hline 4 & Khao Yen Jeen & Smilax sp. & Smilacaceae & Rhizomes & \\
\hline 5 & Hua Ta Pead & Stemona involuta Inthachub. & Stemonaceae & Roots & \multirow{2}{*}{$\begin{array}{c}\text { Chachoengsao } \\
\text { Province, } \\
\text { Thailand }\end{array}$} \\
\hline 6 & Non Tai Yak & Stemona collinsae Craib. & Stemonaceae & Roots & \\
\hline 7 & Thong Pan Chang & Rhinacanthus nasutus (L.) Kurz. & Acanthaceae & Aerial part & \multirow{2}{*}{$\begin{array}{c}\text { Chanthaburi } \\
\text { Province, } \\
\text { Thailand }\end{array}$} \\
\hline 8 & Ngueak plaamo & Acanthus ilicifolius L. & Acanthaceae & Aerial part & \\
\hline
\end{tabular}

developed and approved for effective psoriasis treatment [8]. However, as a great concern about these therapies, the effect of long-term chronic immunosuppression has potential to increase the risks of infection and cancer [6]. In addition, the well-documented arrays of adverse effects result in decrease of patient's adherence. Therefore, there is a need for novel antipsoriatic drug that would provide improved effectiveness but with fewer side effects and lower costs. One of possible solutions is traditional medicine because it provides front-line pharmacotherapy for billions of people worldwide. However, its efficacy related to sufficient preclinical and clinical evidence is often skeptical by the Western medical establishment [9].

Thai traditional medicine employs many different plants for the folk remedy of dermatological conditions [10]. Wannachawee Recipe (WCR) has been enlisted in the Hospital Traditional Medicine Formulary and has been used for the treatment of psoriasis in the Thai Traditional Medicine Clinic of Prapokklao Hospital since 2006. An observational study (2006-2011) indicates that psoriasis accounted for the highest amount of patient attendance at this clinic. There were psoriasis patients (between 13 and 97 years old) with different severity of psoriasis (severe $16.9 \%$, moderate $45.6 \%$, and mild $37.5 \%$ ). For the treatment regimen, patients were prescribed to take $10.77 \mathrm{~g}$ of WCR per day for 6-7 months, and the severity of psoriasis was determined again by certified dermatologists. The results revealed that $93 \%$ of 136 Thai psoriasis patients had good response with WCR, whereas $7 \%$ of them showed less improvement. The factors associated with aggravation of psoriasis among these patients were suggested to be related to particular diet, sleep deprivation, stress, and ultraviolet light and chemical exposure [11]. Although the WCR has been successfully used as a clinical therapy at the Thai Traditional Medicine Clinic for many years, there is still a lack of supporting preclinical evidence supporting the mechanism of pharmacological action of the WCR in psoriasis treatment. The present study aimed to investigate specific mechanism underlying the therapeutic potential of WCR on antiproliferation and anti-inflammatory effects in HaCaT human keratinocytes.

\section{Materials and Methods}

2.1. Chemicals and Reagents. Unless stated, all chemicals and reagents were purchased from Sigma Aldrich Co. (Merck
KGaA, Darmstadt, Germany,). Acitretin $25 \mathrm{mg}$ was obtained from Silom Medical Co., Ltd. (Thailand), and dimethyl sulfoxide (DMSO) from AMRESCO LLC (OH, USA).

2.2. Cell Line. An immortalized human epidermal keratinocyte cell line, HaCaT cell, was purchased from Cell Lines Service GmbH (Eppelheim, Baden-Württemberg, Germany). They were cultured in Dulbecco's modified Eagle's medium (DMEM/high glucose, Gibco Inc., Grand Island, NY), supplemented with $10 \%$ heat-inactivated fetal bovine serum (FBS) and antibiotics $(100 \mathrm{U} / \mathrm{mL}$ penicillin and $100 \mu \mathrm{g} / \mathrm{mL}$ streptomycin) (all from Gibco Inc.) and maintained at $37^{\circ} \mathrm{C}$ in a humidified atmosphere at $5 \% \mathrm{CO}_{2}$.

2.3. Plant Materials. WCR is composed of 8 Thai herbs as shown in Table 1. Roots of S. involuta and S. collinsae were purchased from Chachoengsao Province, Thailand, whereas the other seven herbal plants were from Chanthaburi contract farming of Thai Traditional Medicine Clinic of Prapokklao Hospital. All herbal plants were primarily verified by qualified Thai traditional doctors. The qualitative and quantitative analyses for both herbal plants and WCR were performed according to the methods in Thai Herbal Pharmacopoeias and WHO guideline [12, 13], by Assoc. Professor Dr. Noppamas Soonthornchareonnon, Mahidol University, Bangkok, Thailand.

Each crude herb was dried in a hot air oven $\left(60^{\circ} \mathrm{C}\right)$ for 3 hours; then it was grounded and sieved. All crude components of WCR were mixed in distilled water and refluxed at $80-100^{\circ} \mathrm{C}$ for 1 hour. The first extract was percolated through a filter cloth, while fresh distilled water was added repeatedly to the crude residual. This second extract was percolated through a filter cloth. The mixtures of the first and second extracts were concentrated by a rotary evaporator under reduced pressure until the water had evaporated and dried by spray apparatus. The yield of WCR was $11.77 \%$ of the fresh weight. The final concentration of WCR crude extract $(100 \mathrm{mg} / \mathrm{mL})$ was prepared by dissolving in DMSO.

2.4. Sulforhodamine B (SRB) Assay. HaCaT cells were seeded in 96-well microtiter plates at a density of 10,000 cells/well and incubated at $37^{\circ} \mathrm{C}$ for $24 \mathrm{~h}$. Control cells were cultured in fresh medium containing no drug. Acitretin and methotrexate were used as positive controls for further experiments; 
therefore the cytotoxic effects of these two drugs were determined. Cells were treated in pentaplicate with 8 concentrations of either methotrexate $(0-25 \mu \mathrm{M})$, acitretin $(0-100 \mu \mathrm{M})$, or WCR $(0-1000 \mu \mathrm{g} / \mathrm{mL})$ and incubated for $24 \mathrm{~h}$. SRB colorimetric assay was performed as previously described by Skehan et al. (1990) [14] and Vichai and Kirtikara (2006) [15]. Briefly, cells were fixed with $100 \mu \mathrm{L}$ of cold $10 \%$ (wt/vol) trichloroacetic acid (TCA) at $4^{\circ} \mathrm{C}$ for $1 \mathrm{~h}$. The plates were washed and dried four times and then stained with $100 \mu \mathrm{L}$ of $0.057 \%$ (wt $/ \mathrm{vol}$ ) SRB dissolved in $1 \%$ acetic acid for $30 \mathrm{~min}$. The plates were subsequently rinsed four times with $1 \%$ (vol/vol) acetic acid to remove unbound dye. The protein-bound dye was solubilized with $200 \mu \mathrm{L}$ of $10 \mathrm{mM}$ Tris base solution ( $\mathrm{pH} \mathrm{10.5)} \mathrm{and} \mathrm{the} \mathrm{absorbance} \mathrm{at} 510 \mathrm{~nm}$ was determined using the Synergy ${ }^{\mathrm{TM}} \mathrm{H} 4$ Hybrid Multi-Mode microplate reader (BioTek Instruments, Inc., Vermont, USA). The percentage of growth inhibition was calculated using the equation shown below. Day 0 means the day that treatment was initiated and cells were fixed after treatment for a nogrowth control.

$\%$ control cell growth

$$
=\frac{\text { mean } \mathrm{OD}_{\text {sample }}-\text { mean } \mathrm{OD}_{\text {day } 0}}{\text { mean } \mathrm{OD}_{\text {neg control }}-\text { mean } \mathrm{OD}_{\text {day } 0}} \times 100,
$$

$\%$ growth inhibition

$=100-\%$ of control cell growth.

For $\mathrm{IC}_{50}$ determination, a dose-response curve between test compound concentrations and percent growth inhibition was plotted. $\mathrm{IC}_{50}$ values were derived using curve-fitting methods.

2.5. CCK-8 Assay. Cell viability of $\mathrm{HaCaT}$ cells was measured with Cell Counting Kit-8 assay (CCK-8 from Dojindo, Kumamoto, Japan) according to the manufacturer's instruction. HaCaT cells were seeded at a density of 10,000 cells/well in 96 -well plates and incubated at $37^{\circ} \mathrm{C}$ for $24 \mathrm{~h}$. Twentyfour hours after the treatment with methotrexate $(0-25 \mu \mathrm{M})$, acitretin $(0-100 \mu \mathrm{M})$, or WCR $(0-1000 \mu \mathrm{g} / \mathrm{mL}), 10 \mu \mathrm{L}$ of CCK-8 was added to each well of the 96 -well plates and incubated for $3 \mathrm{~h}$ in a $\mathrm{CO}_{2}$ incubator. The absorbance of the reaction was measured at $450 \mathrm{~nm}$ with the Synergy H4 Hybrid Multi-Mode microplate reader (BioTek Instruments, Inc., Vermont, USA). The absorbance read from each well was calculated using the equation below to obtain the percentage of cell viability.

$$
\begin{aligned}
& \% \text { cell viability } \\
& \qquad=\frac{\text { mean } \mathrm{OD}_{\text {sample }}-\text { mean } \mathrm{OD}_{\text {blank }}}{\text { mean } \mathrm{OD}_{\text {neg control }}-\text { mean } \mathrm{OD}_{\text {blank }}} \times 100
\end{aligned}
$$

2.6. Cell Cycle. HaCaT cells with a density of $3 \times 10^{5}$ cells/well were cultured in 6 -well plates for $24 \mathrm{~h}$ prior to the experiment. The cells were serum-starved for $24 \mathrm{~h}$ before the treatment. After $48 \mathrm{~h}$ of methotrexate $(0.2 \mu \mathrm{M})$, acitretin
$(20 \mu \mathrm{M})$, or WCR $(25,50$, and $75 \mu \mathrm{g} / \mathrm{mL})$ treatment, cells were harvested by trypsinization. The cells were washed twice with phosphate-buffered saline (PBS) prior to fixation with cold $70 \%$ ethanol. The fixed cells were refrigerated for at least $4 \mathrm{~h}$ at $4^{\circ} \mathrm{C}$ before being stained with Guava ${ }^{\circledR}$ Cell Cycle Reagent (Merck Millipore, CA, USA), which was a fluorogenic compound containing propidium iodide (PI). The stained cells were incubated for $30 \mathrm{~min}$, shielded from the light, and measured for the distribution of the cell cycle phases by using Guava easyCyte Flow Cytometers (Merck Millipore, CA, USA). Data were analyzed using Guava Cytosoft $^{\mathrm{TM}}$ version 4.2 software (Millipore) according to the manufacturer's instructions.

2.7. Real-Time Reverse Transcription Polymerase Chain Reaction (RT-qPCR). HaCaT cells $\left(3 \times 10^{5}\right.$ cells/well) were seeded into 6-well plates and incubated $24 \mathrm{~h}$. The cells were pretreated with $20 \mu \mathrm{M}$ of acitretin or $50-100 \mu \mathrm{g} / \mathrm{mL}$ of WCR for $1 \mathrm{~h}$ and inflammation was stimulated with the addition of TNF- $\alpha$ and IFN- $\gamma$ (10 ng/mL each) (PEPROTECH, USA) for $12 \mathrm{~h}$ before harvesting cells.

To detect the mRNA expression, total RNA was extracted by using FavorPrep ${ }^{\mathrm{TM}}$ Total RNA Purification Mini Kit (Favorgen Biotech Corp., Taiwan). The quantity of total RNA was estimated using Nano-Drop spectrophotometer (Thermo Fisher Scientific, USA). RNA was reverse transcribed using ReverTra Ace ${ }^{\circledR}$ qPCR RT Master mix with gDNA Remover (TOYOBO, Japan), following the manufacturer's instruction. Six microliters of RNA template $(1.5 \mu \mathrm{g} / \mu \mathrm{L})$ was gently added to $6 \mu \mathrm{L}$ of $4 \mathrm{x}$ DN Master Mix (containing gDNA remover) and $12 \mu \mathrm{L}$ nuclease-free water, and the mixture was incubated for $5 \mathrm{~min}$ at $37^{\circ} \mathrm{C}$. The solution was added with $6 \mu \mathrm{L}$ of $5 \mathrm{x}$ RT Master Mix II, and reverse transcription was performed $\left(37^{\circ} \mathrm{C}\right.$ for $15 \mathrm{~min}, 50^{\circ} \mathrm{C}$ for $5 \mathrm{~min}$, and $98^{\circ} \mathrm{C}$ for $5 \mathrm{~min}$ ). The resulting complementary (c)DNA was used as a template for quantitative PCR using the PCRmax Eco 48 realtime PCR system (PCRmax Limited, UK) with PerfeCTa ${ }^{\mathrm{TM}}$ SYBR $^{\circledR}$ Green FastMix ${ }^{\mathrm{TM}}$, Low Rox $^{\mathrm{TM}}$ (Quanta Biosciences ${ }^{\mathrm{TM}}$, USA), in accordance with the manufacturer's protocol. The reaction mixture consisted of $2 \mu \mathrm{L}$ cDNA, $1 \mu \mathrm{L}$ nuclease-free water, $5 \mu \mathrm{L}$ PerfeCTa SYBR Green FastMix, Low Rox, and $1 \mu \mathrm{L}(100 \mathrm{nM})$ of each specific primer (Table 2$)$. PCR was performed under the following conditions: $95^{\circ} \mathrm{C}$ for $3 \mathrm{~min}, 45$ cycles of $95^{\circ} \mathrm{C}$ for $10 \mathrm{~s}, 56^{\circ} \mathrm{C}$ for $15 \mathrm{~s}, 72^{\circ} \mathrm{C}$ for $30 \mathrm{~s}, 95^{\circ} \mathrm{C}$ for $15 \mathrm{~s}$ to detect the melting curve, $55^{\circ} \mathrm{C}$ for $15 \mathrm{~s}$, and $95^{\circ} \mathrm{C}$ for $15 \mathrm{~s}$.

2.8. Enzyme-Linked Immunosorbent Assay (ELISA). TNF- $\alpha$ and IFN- $\gamma$ can induce production and secretion of several inflammatory cytokines in $\mathrm{HaCaT}$ cells. The concentration of IL-17A, IL-22, and IL-23 in the supernatant of HaCaT cells was measured using human IL-17A, IL-22, and IL23 ELISA MAX ${ }^{\mathrm{TM}}$ Deluxe (BioLegend, USA). ELISA was performed as recommended by the manufacturer. Briefly, the ELISA plate was coated with $100 \mu \mathrm{L}$ of $1 \mathrm{x}$ capture antibody in coating buffer and incubated overnight at $4^{\circ} \mathrm{C}$. The plate was washed with wash buffer (0.05\% Tween-20 in PBS) four times and then blocked with $200 \mu \mathrm{L}$ of blocking buffer for $1 \mathrm{~h}$ at room temperature. After blocking, the plate was washed with wash buffer for four times. Human IL-17A, IL-22, and 
TABle 2: Primer sequences.

\begin{tabular}{ll}
\hline Gene name & Sequence \\
\hline Forward GAPDH & ACCACAGTCCATGCCATCAC \\
Reverse GAPDH & TCCACCACCCTGTTGCTGTA \\
\hline Forward IL-1 $\beta$ & AGCTCGCCAGTGAAATGATG \\
Reverse IL-1 $\beta$ & TGGTGGTCGGAGATTCGTAG \\
\hline Forward IL-6 & CCACTCACCTCTTCAGAACG \\
Reverse IL-6 & CATCTTTGGAAGGTTCAGGTTG \\
\hline Forward IL-8 & GGTGCAGTTTTGCCAAGGAG \\
Reverse IL-8 & TTCCTTGGGGTCCAGACAGA \\
\hline Forward IL-10 & TGTTCTTTGGGGAGCCAACA \\
Reverse IL-10 & GGCTCCCTGGTTTCTCTTCC \\
\hline Forward IL-17A & GCTGATGGGAACGTGGACTA \\
Reverse IL-17A & TAGGCCACATGGTGGACAATC \\
\hline Forward IL-22 & CCAGCCTTATATGCAGGAGG \\
Reverse IL-22 & TTTCAGCTTTGCTCTGGTCA \\
\hline Forward IL-23 & AAACCAGAGACGCGCTGAA \\
Reverse IL-23 & GCAGCAACAGCAGCATTACA \\
\hline Forward TNF- $\alpha$ & TGGGATCATTGCCCTGTGAG \\
Reverse TNF- $\alpha$ & CCAGGTTTCGAAGTGGTGGT \\
\hline
\end{tabular}

IL-23 standards were diluted to reach the concentrations of $0-1000 \mathrm{pg} / \mathrm{mL}$. One hundred microliters of the standards or samples was added to each well in triplicate for $2 \mathrm{~h}$ at room temperature. The ELISA plate was washed four times, added with $100 \mu \mathrm{L}$ of the specific detection antibody for $1 \mathrm{~h}$ at room temperature, and washed four times. AvidinHRP conjugated $(1: 1000)(100 \mu \mathrm{L})$ was added and incubated for $30 \mathrm{~min}$ followed by washing for five times. Finally, the freshly mixed TMB substrate solution $(100 \mu \mathrm{L})$ was added into each well and incubated in the dark for $30 \mathrm{~min}$. The stop solution $\left(2 \mathrm{~N} \mathrm{H}_{2} \mathrm{SO}_{4}\right)(100 \mu \mathrm{L})$ was added to each well and the absorbance at $450 \mathrm{~nm}$ and $570 \mathrm{~nm}$ was measured within 15 min by using the Synergy H4 Hybrid Multi-Mode microplate reader (BioTek Instruments, Inc., Vermont, USA).

2.9. Statistical Analysis. Data were analyzed by one-way analysis of variance (one-way ANOVA), followed by post hoc Fisher's least significant difference (LSD) test using the SPSS for Windows (version 20.0). Differences were considered significant at $p<0.05$. All experiments were performed in triplicate using a minimum of three experiment trials. All values are expressed as mean \pm standard error of mean (SEM).

\section{Results}

3.1. Cytotoxicity of the WCR on HaCaT Cells. To examine their cytotoxicity, HaCaT cells were treated with different concentrations of WCR, acitretin, and methotrexate for $24 \mathrm{~h}$. The cell growth and viability were determined by SRB and CCK-8 assays, respectively. As shown in Figure 1(a), WCR inhibited the growth of keratinocytes in a concentrationdependent manner, with a maximum inhibition around $60 \%$ for the highest concentration tested $(1000 \mu \mathrm{g} / \mathrm{mL})$. Likewise, CCK-8 assay showed that the cell viability was reduced in a concentration-dependent manner. The $\mathrm{IC}_{50}$ values from SRB and CCK- 8 assays after the $24 \mathrm{~h}$ treatment of WCR were approximately $643.90 \pm 73 \mu \mathrm{g} / \mathrm{mL}$ and $575 \pm 35.96 \mu \mathrm{g} / \mathrm{mL}$, respectively. Acitretin (Figure 1(b)) and methotrexate (Figure 1(c)) were used as a positive control which undoubtedly showed effective inhibition of cell growth and cell viability at low concentrations. The nontoxic concentrations of drugs and WCR were chosen to further evaluate changes in molecular events.

3.2. Flow Cytometric Analysis of HaCaT Cells. For better understanding the mechanism of inhibition of cell proliferation, possible cell arrest at specific phases of the cell cycle was analyzed following treatment of $\mathrm{HaCaT}$ with methotrexate, acitretin, or WCR for $48 \mathrm{~h}$. Cell viability and cytotoxicity tests at $48 \mathrm{~h}$ were also performed and the trend was similar to that in cells treated with methotrexate, acitretin, or WCR for $24 \mathrm{~h}$ (data not shown). The amount of living cells was measured through stoichiometric detection of nucleic acid bound with PI and sent off fluorescent emission proportional to the DNA content of a cell [16]. The flow cytometric data on PI-stained HaCaT cells are shown in Figure 2. The treatment of WCR $(25,50$, and $75 \mu \mathrm{g} / \mathrm{mL})$ and acitretin $(20 \mu \mathrm{M})$ at nontoxic concentrations had no effect on cell cycle distribution compared with the control group. However, methotrexate treatment significantly increased the percentage of cells at the S-phase.

3.3. Inhibitory Effects of WCR on mRNA Expression of Cytokines in TNF- $\alpha$ - and IFN- $\gamma$-Stimulated HaCaT Cells. To investigate the effect of WCR on suppressing the production of proinflammatory cytokines in the keratinocytes, $\mathrm{HaCaT}$ cells were exposed to TNF- $\alpha(10 \mathrm{ng} / \mathrm{mL})$ and IFN- $\gamma$ $(10 \mathrm{ng} / \mathrm{mL})$ with or without the presence of WCR. As shown in Figure 3, the upregulation of IL-1 $\beta$, IL-6, IL-8, IL-17A, IL22 , IL-23, and TNF- $\alpha$ expression was markedly decreased in the groups treated with acitretin and WCR. In contrast, the presence of acitretin and WCR significantly potentiated TNF$\alpha$ - and IFN- $\gamma$-induced IL-10 gene expression (Figure 3(h)). Specifically, the inhibitory activities of $20 \mu \mathrm{M}$ acitretin, $50 \mu \mathrm{g} / \mathrm{mL} \mathrm{WCR}$, and $100 \mu \mathrm{g} / \mathrm{mL}$ WCR on IL- $1 \beta$, IL-17A, and IL-22 expression in HaCaT cells were approximately 3fold, 2-fold, and 3-fold, respectively, greater than the cells stimulated with TNF- $\alpha$ and IFN- $\gamma$ alone (Figures 3(a), 3(d), and 3(e)). Moreover, in comparison to HaCaT cells with TNF- $\alpha$ and IFN- $\gamma$ stimulation alone, approximately a 2 -fold decrease in IL- 6 and IL-8 expression and a 3-fold decrease in TNF- $\alpha$ expression were observed in the groups treated with both $20 \mu \mathrm{M}$ of acitretin and $50-100 \mu \mathrm{g} / \mathrm{mL}$ of WCR (Figures $3(\mathrm{~b}), 3(\mathrm{c})$, and 3(g)). Furthermore, the presence of acitretin $20 \mu \mathrm{M}$, WCR $50 \mu \mathrm{g} / \mathrm{mL}$, and WCR $100 \mu \mathrm{g} / \mathrm{mL}$ suppressed the expression of IL-23 for 2-fold, 2-fold, and 19-fold, respectively, as compared with $\mathrm{HaCaT}$ cells stimulated with TNF- $\alpha$ and IFN- $\gamma$ alone (Figure 3(f)). Interestingly, we discovered that the induction of HaCaT cells by TNF- $\alpha$ and IFN- $\gamma$ decreased IL-10 expression three times lower than the negative control cells. However, after the treatment with $20 \mu \mathrm{M}$ of acitretin, $50 \mu \mathrm{g} / \mathrm{mL}$ of WCR, and $100 \mu \mathrm{g} / \mathrm{mL}$ of WCR, IL-10 expression was 2-fold, 3-fold, and 3-fold higher than cells treated with TNF- $\alpha$ and IFN- $\gamma$ alone (Figure $3(\mathrm{~h})$ ). 


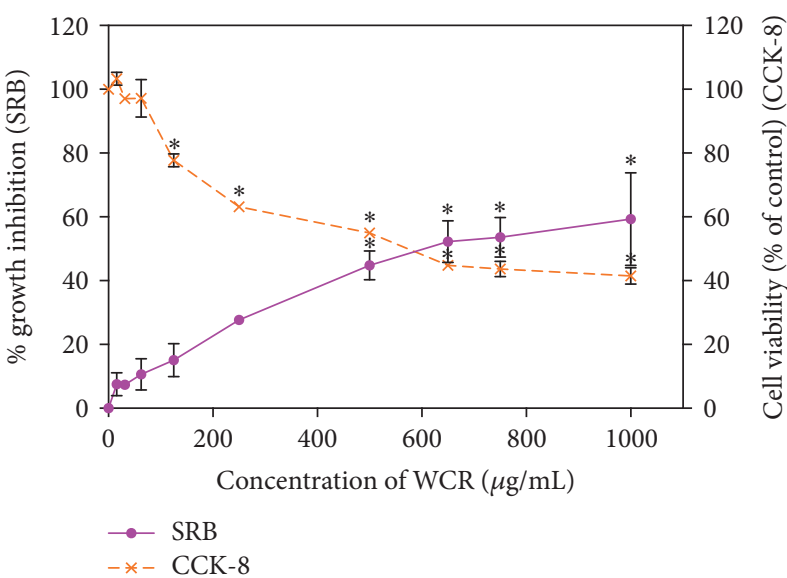

(a)

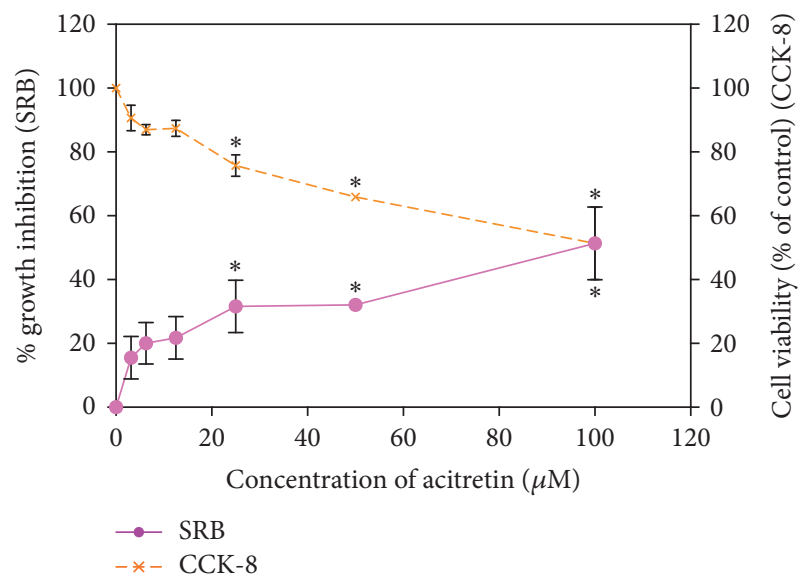

(b)

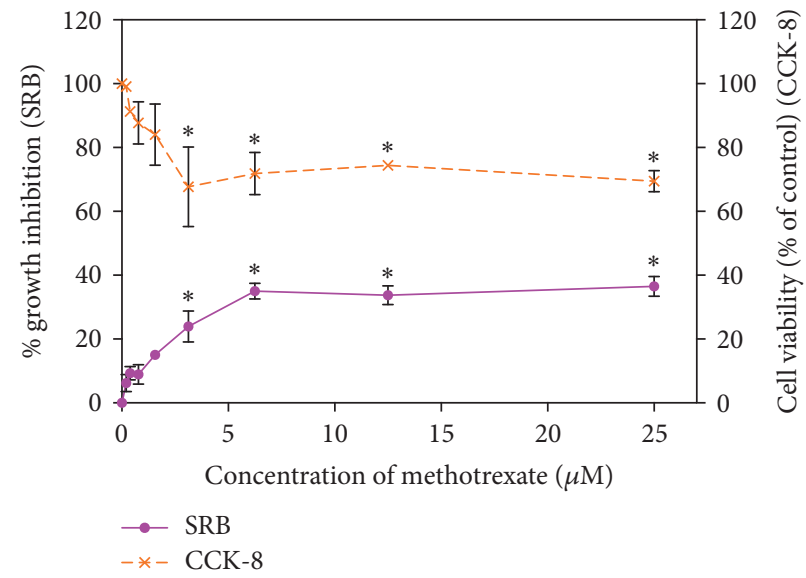

(c)

FIGURE 1: Growth inhibition and cell viability of HaCaT cells treated with WCR. (a) Cells treated with WCR $(0-1000 \mu \mathrm{g} / \mathrm{mL}),(\mathrm{b})$ cells treated with acitretin $(0-100 \mu \mathrm{M})$, and (c) cells treated with methotrexate $(0-25 \mu \mathrm{M})$. Data are presented as mean \pm SEM $(n=4) .{ }^{*} p<0.05$ compared with untreated cells.

3.4. Inhibitory Effects of WCR on Cytokine Secretion in TNF$\alpha$ - and IFN- $\gamma$-Stimulated HaCaT Cells. Focusing on three major proinflammatory cytokines (IL-17A, IL-22, and IL23) responsible for development of psoriasis, the secretion of IL-17A, IL-22, and IL-23 in the culture supernatants of cells stimulated with TNF- $\alpha$ and IFN- $\gamma$, with or without the presence of WCR, was quantitatively evaluated by ELISA. As shown in Figure 4, cells stimulated with TNF- $\alpha$ and IFN- $\gamma$ significantly increased the levels of IL-17A, IL-22, and IL-23 in the culture supernatants of $\mathrm{HaCaT}$ cells to 2-fold, 2-fold, and 3 -fold, respectively, compared with the nonstimulated cells $(p<0.001)$. Although the production levels of IL-17A, IL-22, and IL-23 in the stimulated cells were not statistically different from the cells treated with the $50 \mu \mathrm{g} / \mathrm{mL}$ WCR, treatment with $100 \mu \mathrm{g} / \mathrm{mL}$ of WCR, and $20 \mu \mathrm{M}$ of acitretin significantly reduced the TNF- $\alpha$ - and IFN- $\gamma$-stimulated IL-17A and IL22 production for 1.5 -fold ( $p<0.05$ ) (Figures $4(\mathrm{a})$ and $4(\mathrm{~b}))$. In addition, the presence of $20 \mu \mathrm{M}$ acitretin, $50 \mu \mathrm{g} / \mathrm{mL}$ $\mathrm{WCR}$, and $100 \mu \mathrm{g} / \mathrm{mL}$ WCR inhibited the production of IL23 for 1.8-fold, 1.3-fold, and 7-fold, respectively, compared with the HaCaT cells stimulated with TNF- $\alpha$ and IFN- $\gamma$ alone (Figure 4(c)).

\section{Discussion}

Traditional herbal medicines are clearly attractive drug candidates in health maintenance for Asian people and becoming more frequently used in the western countries [17]. Only one system of folk remedy officially accepted by Thai Ministry of Public Health is a traditional herbal medicine based on the element theory, consisting of earth (solidity), water (fluidity), fire (heat), and wind (motion). Psoriasis is caused by an imbalance among these four elements [18]. WCR is composed of 8 different crude plant extracts and has been shown to be effective for alleviating psoriasis of patients at Thai Traditional Medicine Clinic of Prapokklao Hospital since 2006. A previous study has shown that WCR has a clinical effect of $93 \%$ on blood-heat type psoriasis [11]. However, preclinical evidence defining how WCR works is still lacking. The present study investigated a specific mechanism underlying the therapeutic potential of WCR to be certain whether WCR has antiproliferation and antiinflammatory effects.

As a primary bioassay screening of the potential drugs for psoriasis treatment, the inhibition of keratinocyte 

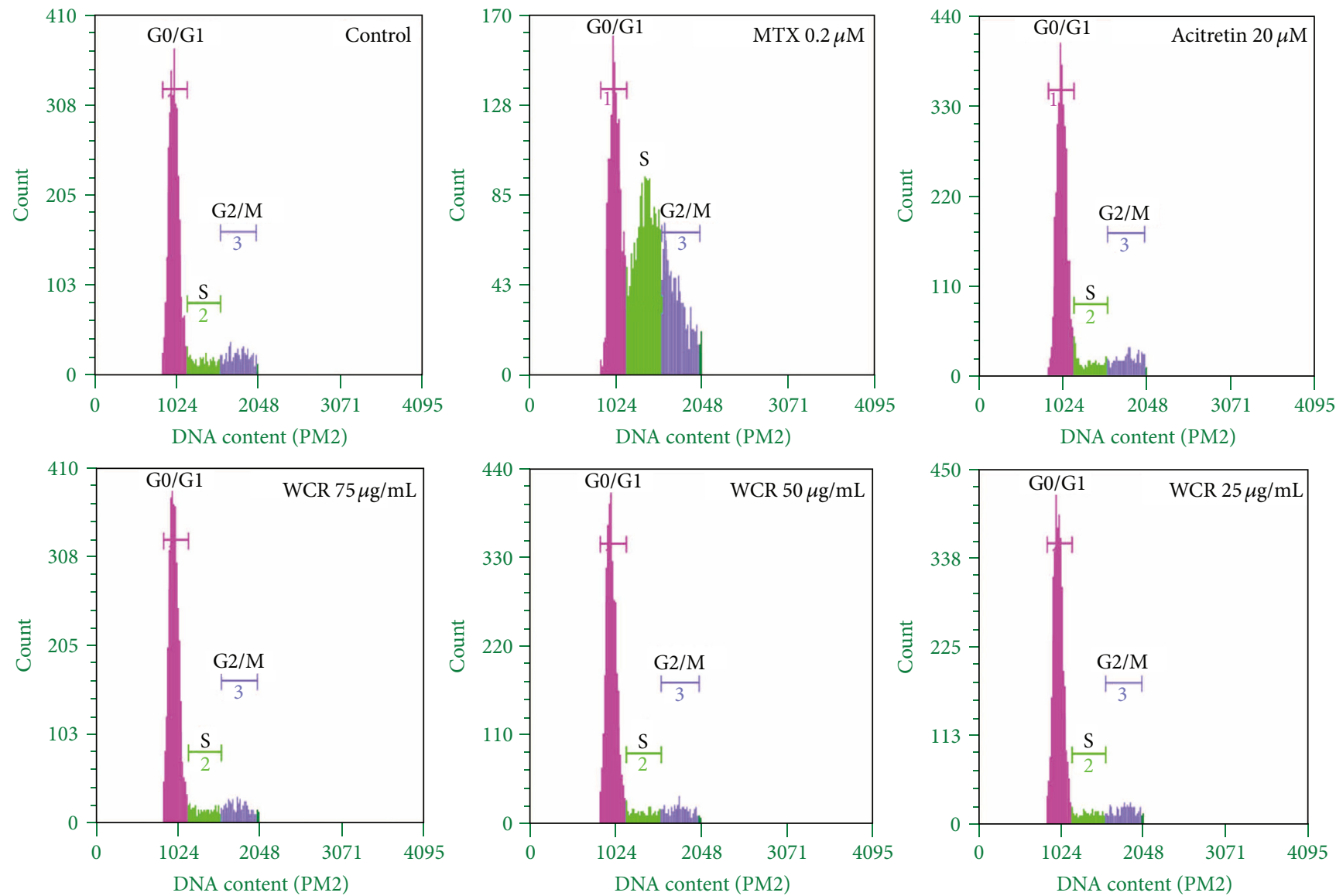

(a)

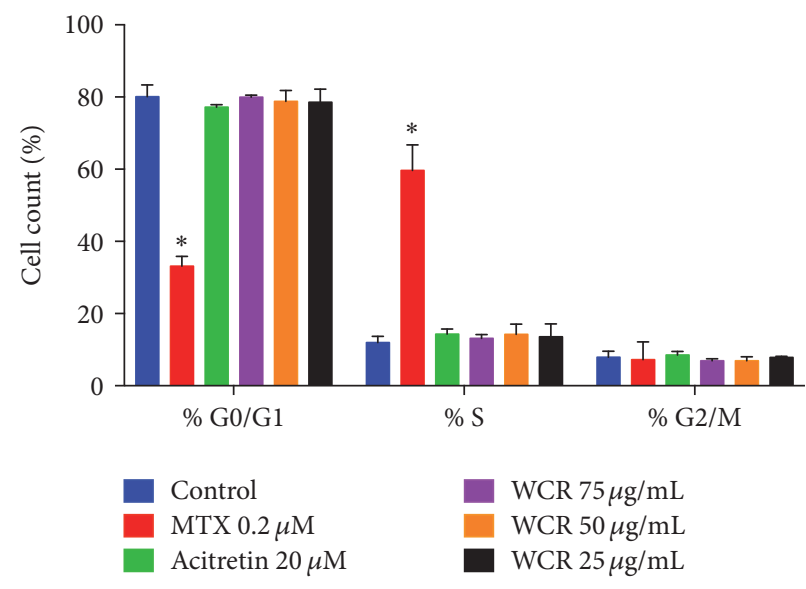

(b)

Figure 2: Percentage of cell cycle distribution (G0/G1, S, and G2/M phases) of cells treated with methotrexate, WCR, and acitretin. (a) Typical histogram from flow cytometry with PI staining. (b) Histogram representing cell cycle distribution of HaCaT cells treated with medium alone (control), $0.2 \mu \mathrm{M}$ of methotrexate (MTX), $20 \mu \mathrm{M}$ of acitretin, $75 \mu \mathrm{g} / \mathrm{mL}$ of WCR, $50 \mu \mathrm{g} / \mathrm{mL}$ of WCR, or $25 \mu \mathrm{g} / \mathrm{mL}$ of WCR. Data are expressed as mean $\pm \operatorname{SEM}(n=3) .{ }^{*} p<0.0001$ compared with control cells.

proliferation is considered as a crucial parameter. At the tested concentrations of $0-1000 \mu \mathrm{g} / \mathrm{mL}$, WCR had cytotoxicity effect on $\mathrm{HaCaT}$ cells as measured by SRB assay. Consistent with the SRB assay result, the cell viability was examined by
CCK-8 assay, which determined mitochondrial dehydrogenase activities in the living cells [19]. WCR had a significant cytotoxicity effect on $\mathrm{HaCaT}$ cells in a concentrationdependent manner, with $\mathrm{IC}_{50}$ approximately $600 \mu \mathrm{g} / \mathrm{mL}$. 


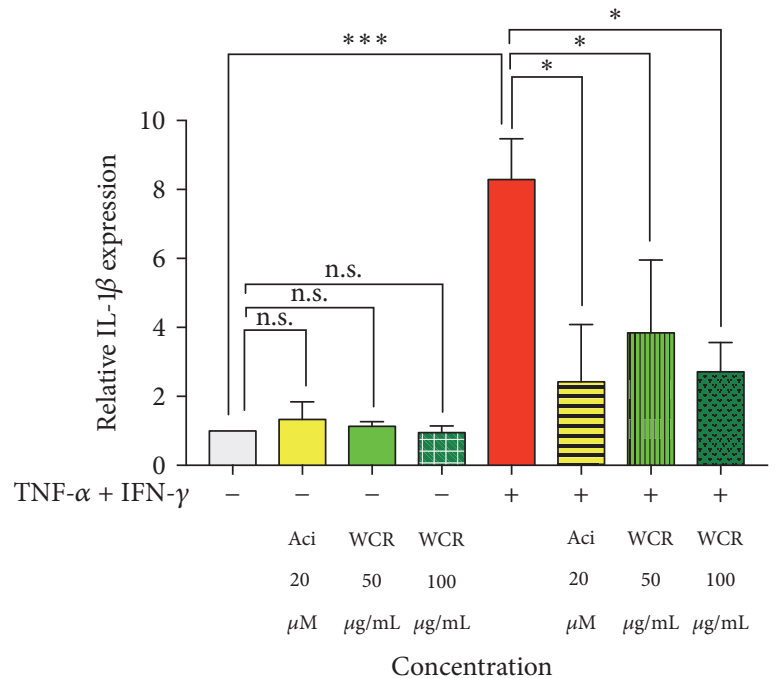

(a)

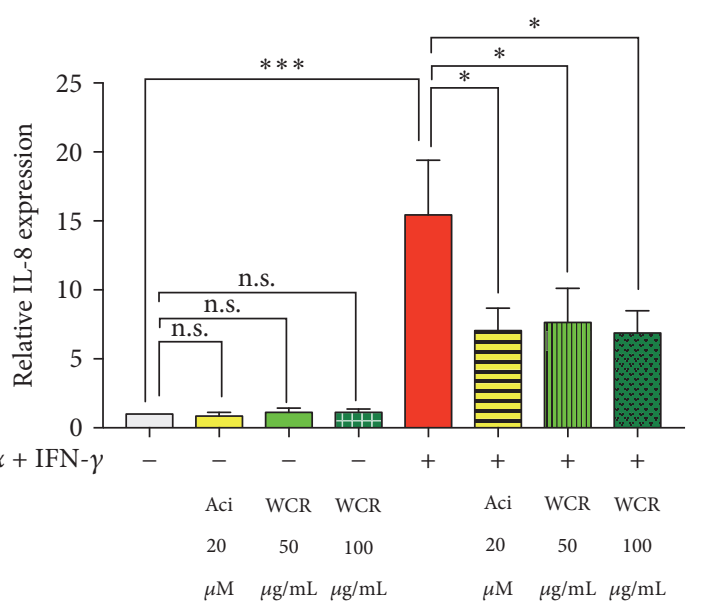

Concentration

(c)

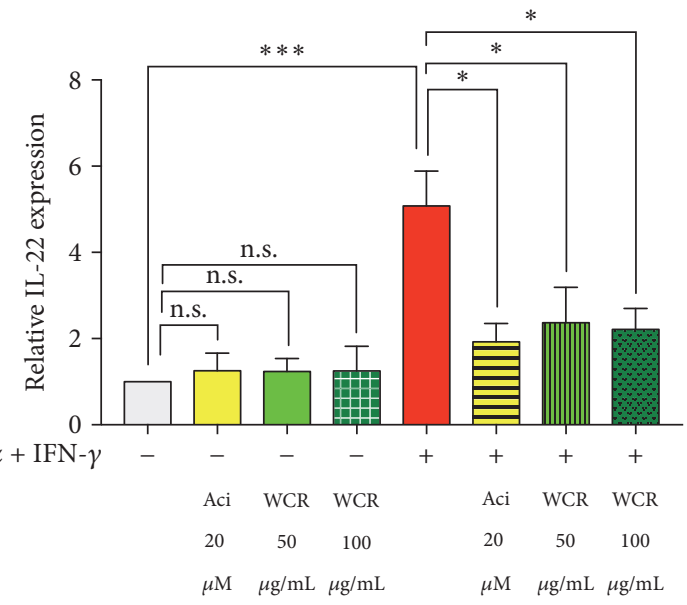

Concentration

(e)

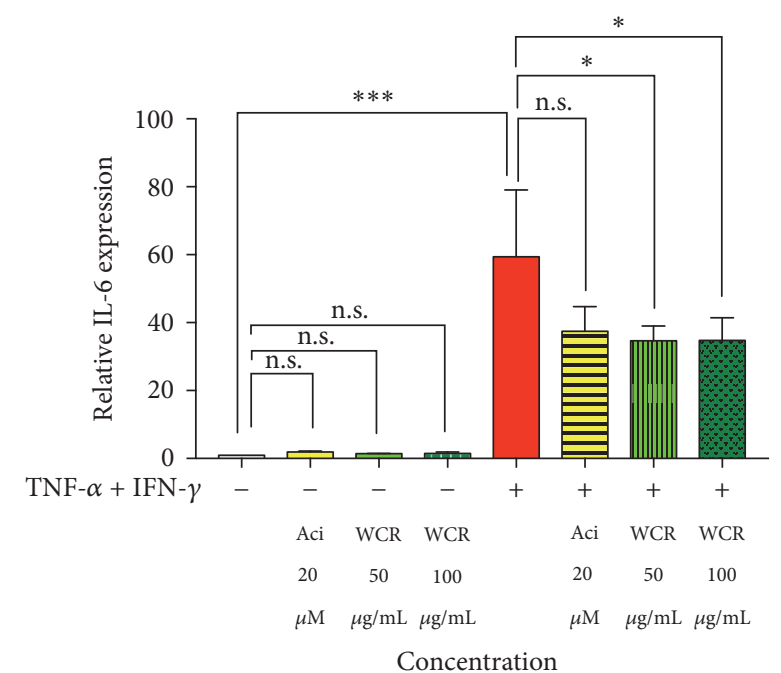

(b)

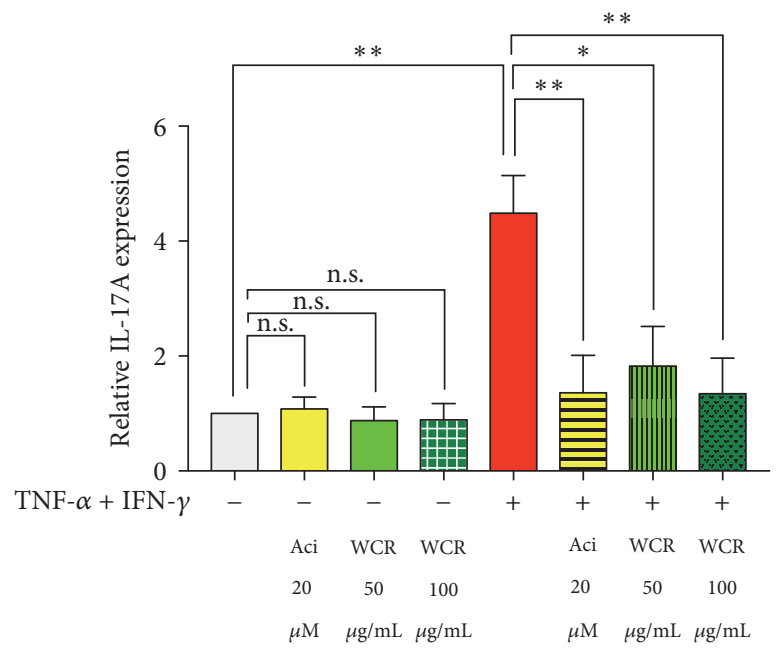

Concentration

(d)

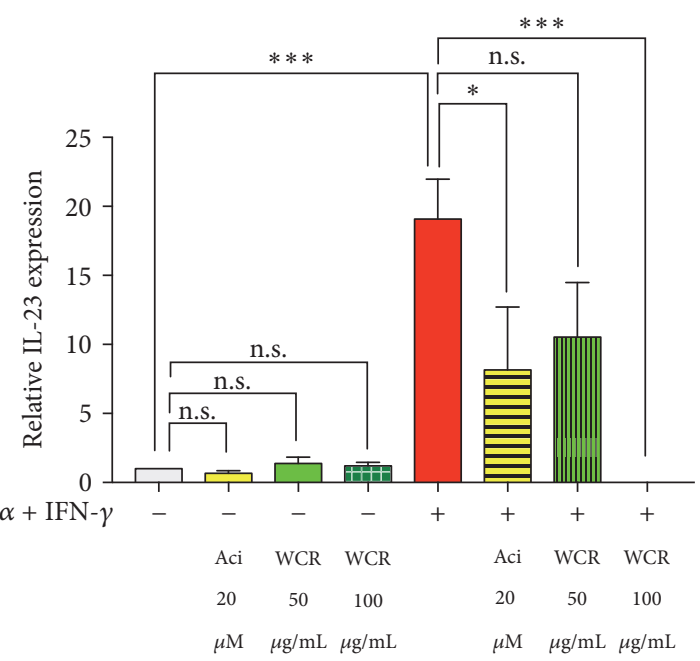

Concentration

(f)

FIgure 3: Continued. 


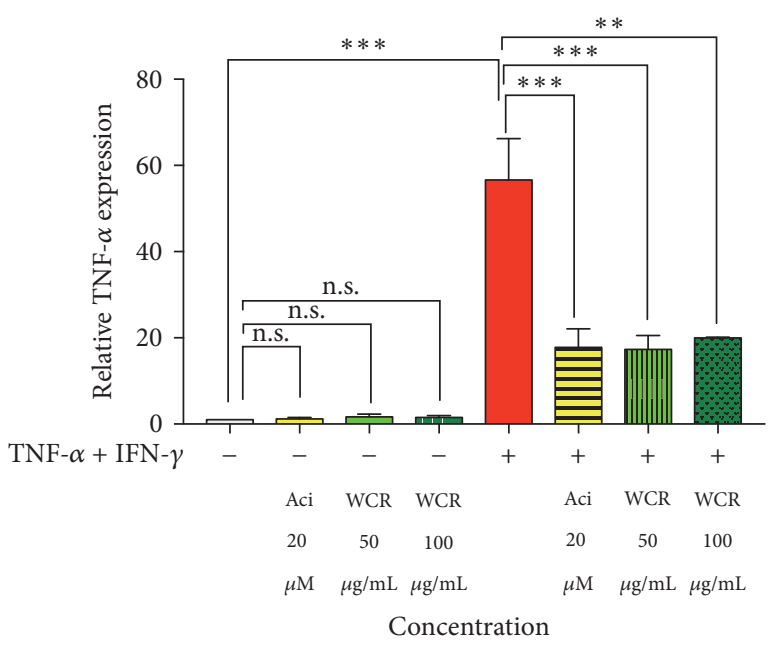

(g)

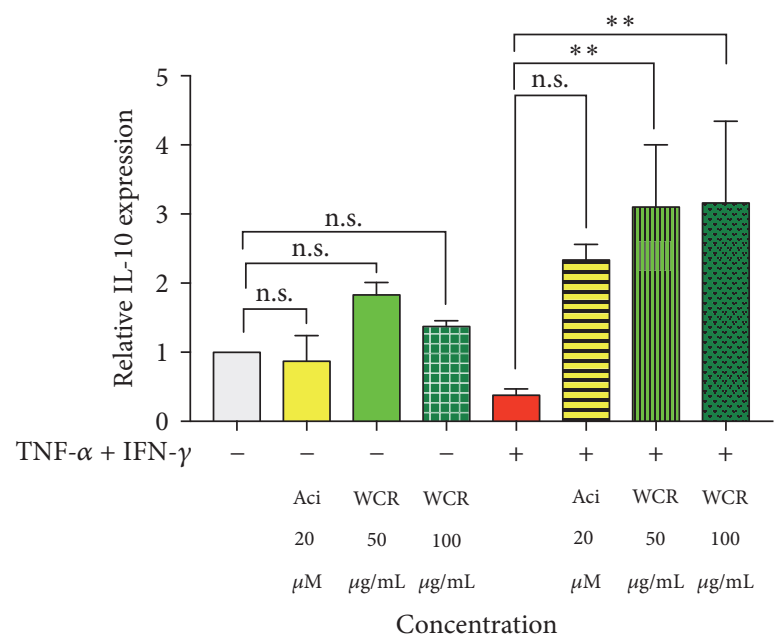

(h)

FIGURE 3: Effects of WCR on cytokine expression in TNF- $\alpha$ - and IFN- $\gamma$-stimulated HaCaT cells. Relative expression levels of IL-1 $\beta$ (a), IL-6 (b), IL-8 (c), IL-17A (d), IL-22 (e), IL-23 (f), TNF- $\alpha$ (g), and IL-10 (h). Data are expressed as mean \pm SEM of three independent experiments; n.s., not significant. ${ }^{*} p<0.05,{ }^{* *} p<0.005$, and ${ }^{* * *} p<0.001$ compared with TNF- $\alpha$ and IFN- $\gamma$ treated cells.

The results strongly suggest that WCR contains active constituents that suppress growth of the cell and stimulate cell death. Unsurprisingly, acitretin and methotrexate, which are the drug of choice for the conventional psoriasis treatment, exhibited strong inhibitory effect on the cells. Previous studies have been reported about the effect of S. glabra on $\mathrm{HaCaT}$ cell lines, showing $\mathrm{IC}_{50}$ more than $200 \mu \mathrm{g} / \mathrm{mL}$ [20]. It is therefore reasonable that $S$. glabra may be considered to be a major active ingredient of WCR that plays a crucial role in inducing cytotoxicity. In the present study, exposure of cells with WCR at concentrations over $100 \mu \mathrm{g} / \mathrm{mL}$ resulted in dramatic inhibition of $\mathrm{HaCaT}$ cell growth, whereas treating $\mathrm{HaCaT}$ cells for $24 \mathrm{~h}$ with less than $100 \mu \mathrm{g} / \mathrm{mL}$ WCR resulted in a $90 \%$ survival rate. Although these concentrations of WCR do not kill cells, they may play significant roles in suppressing some important signal transductions such as cell cycle and inflammation pathways.

Cell cycle analysis was performed to elucidate whether WCR interferes with a normal cycle of cell division. Therefore, three nontoxic concentrations of $\operatorname{WCR}(25,50$, and $75 \mu \mathrm{g} / \mathrm{mL}$ ) were examined for its effect on each phase of cell cycle compared with the positive controls, including methotrexate and acitretin. The results indicated that WCR and acitretin had no effect on the induction of cell cycle arrest, while methotrexate significantly induced S-phase arrest. In line with these results, previous evidence demonstrated that methotrexate acts specifically on the process of DNA synthesis (S-phase) by means of its irreversibly binding to the enzyme dihydrofolate reductase $[21,22]$. The binding of methotrexate to dihydrofolate reductase results in a depletion of intracellular tetrahydrofolate pools and leads to a reduction of DNA synthesis and, therefore, exerts its cytotoxic activity in a cell-cycle-specific manner $[21,22]$. The methotrexate toxicity, ranging from the unpleasant to the fatal, has severely limited its dose and duration of treatment [21, 22].
Moreover, in accordance with Lin et al., acitretin did not affect the viability of normal keratinocytes, but it was able to induce apoptosis in skin squamous cell carcinoma (SCL1) cells [23]. In contrast, Liwei et al. revealed that retinoids altered cell cycle distribution of tongue squamous cell carcinoma (Tca8113) cells by increasing G0/G-phase population, decreasing in S-phase population, and inhibiting of G1/S switching [24]. In the present study, WCR did not cause any difference in the cell cycle profile, indicating that particular concentrations of WCR do not interfere with normal function of molecular executors in cell cycle signaling and, therefore, do not interrupt the cell cycle.

Extensive evidence has shown the involvement and role of T cells with a mixed proinflammatory Th1/Th17 cytokine in pathogenesis of psoriasis through causing inflammation, neovascularization, and hyperproliferation of keratinocytes $[25,26]$. Herein, we found that $\mathrm{HaCaT}$ cells treated with TNF- $\alpha$ and IFN- $\gamma$ alone markedly decreased the expression of IL-10 but increased that of various cytokine genes, including IL-1 $\beta$, IL-6, IL-8, IL-17A, IL-22, IL-23, and TNF$\alpha$ in HaCaT cells. This finding is also consistent with that of previous studies [27-29]. In contrast, the level of IL-10 gene expression after TNF- $\alpha$ and IFN- $\gamma$ exposure was significantly potentiated by both $50 \mu \mathrm{g} / \mathrm{mL}$ and $100 \mu \mathrm{g} / \mathrm{mL}$ of WCR. It should be noted that IL-10 produced by regulatory $\mathrm{T}$ cells has been characterized as an anti-inflammatory cytokine and shown to suppress proinflammatory $\mathrm{T}$ cell production and keratinocyte inflammatory markers [26, 30]. As IL-10 has demonstrated promise in a phase II trial for cutaneous disorders [30], therefore, our observation that IL-10 gene was drastically upregulated suggests that WCR may have antipsoriatic properties.

WCR exerts anti-inflammatory activity since the extract at $50 \mu \mathrm{g} / \mathrm{mL}$ and $100 \mu \mathrm{g} / \mathrm{mL}$ significant decreases the expression of various inflammatory cytokines (IL-1 $\beta$, IL-6, IL-8, 


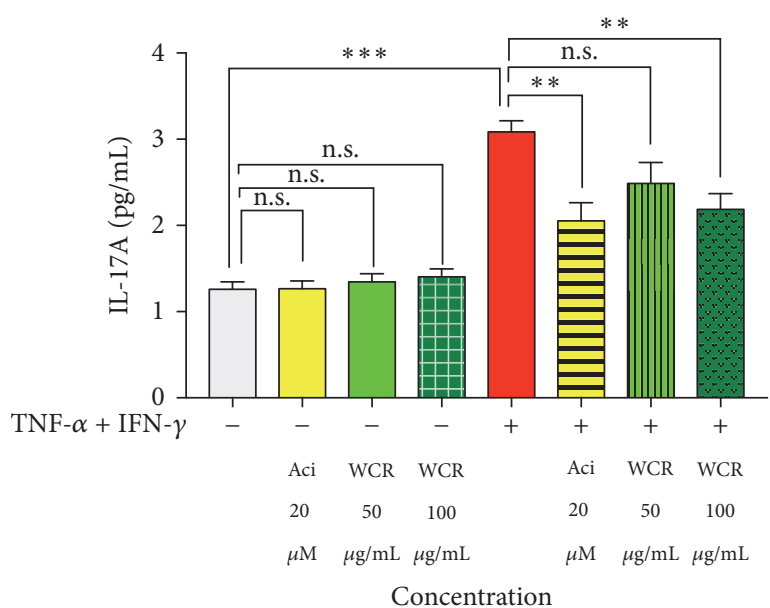

(a)

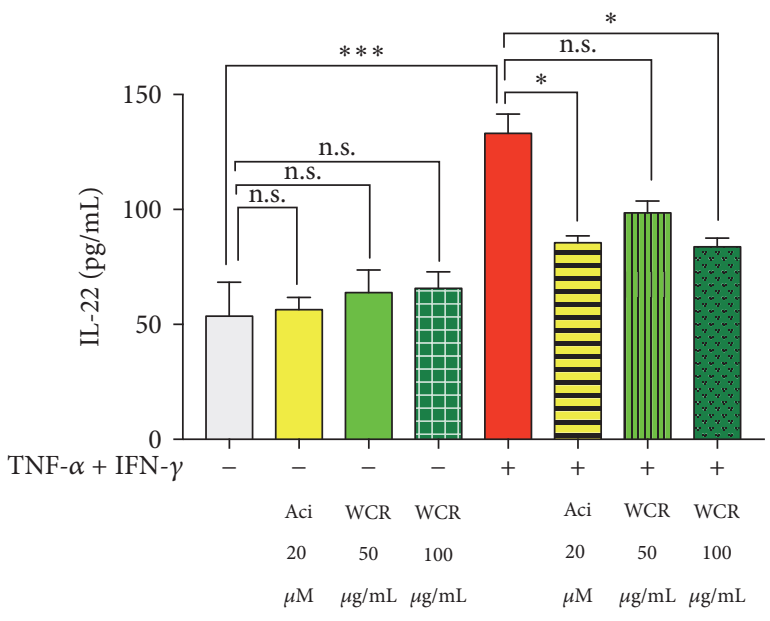

Concentration

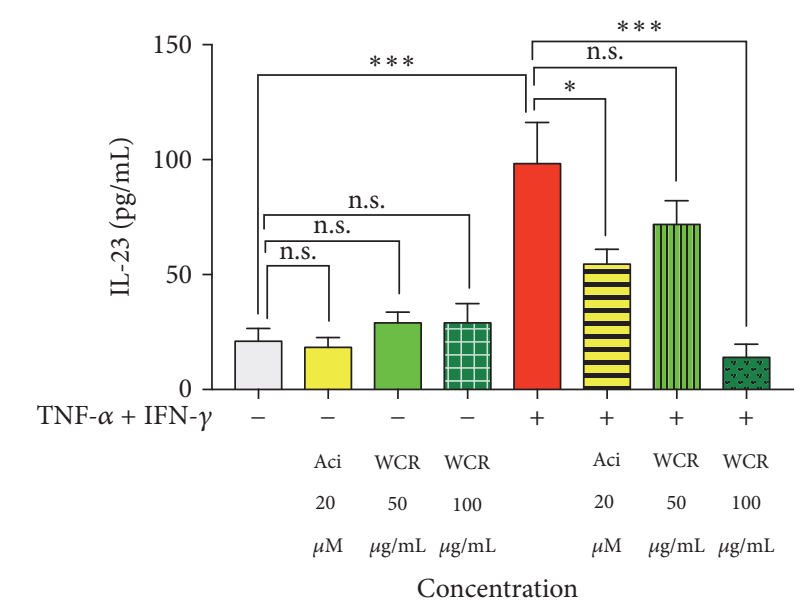

(c)

FIGURE 4: Effects of WCR on cytokine secretion in TNF- $\alpha$ - and IFN- $\gamma$-stimulated HaCaT cells. ELISA was performed to determine the concentration of IL-17A, IL-22, and IL-23 in the culture supernatants of cells treated with TNF- $\alpha$ and IFN- $\gamma$ (each $10 \mathrm{ng} / \mathrm{mL}$ ) for $24 \mathrm{~h}$ with or without the presence of WCR $(50$ and $100 \mu \mathrm{g} / \mathrm{mL})$. Acitretin $(20 \mu \mathrm{M})$ was used as a positive control; n.s., not significant. Data are expressed as mean \pm SEM of three independent experiments. ${ }^{*} p<0.05,{ }^{* *} p<0.005$, and ${ }^{* * *} p<0.001$ compared with TNF- $\alpha$ and IFN- $\gamma$ treated cells.

IL-17A, IL-22, IL-23, and TNF- $\alpha$ ) in HaCaT cells stimulated with TNF- $\alpha$ and IFN- $\gamma$. In agreement with our findings, previous reports do suggest that terpenes and flavonoids found in A. galanga, which is one of major active components of WCR, have strong antioxidant and anti-inflammatory activities [31]. A. galanga can also reduce the expression of $\mathrm{NF}-\kappa \mathrm{B}$ signaling biomarkers via an increased expression of a molecule inhibiting NF- $\kappa \mathrm{B}$ (TNFAIP3) [10], leading to a decrease in cytokine production by T cells [31]. Other studies reported that the flavonoid astilbin isolated from the rhizome of S. glabra, another major active component of WCR, has an inhibitory effect on Jak/Stat3 signaling in Th17 cells [32] and inhibits production of nitric oxide, TNF- $\alpha$, and IL- 6 production [33] through p65, ERK1/2, and JNK pathways [34]. Astilbin also downregulates $\mathrm{T}$ cell function by suppressing activated $\mathrm{T}$ cell migration and adhesion and stimulating negative regulatory interleukin 10 (IL-10) production [35, 36]. In addition, anti-inflammatory, antiproliferative, and antioxidant activities have been well-documented for other components of WCR, including S. corbularia [37], R. nasutus $[38,39]$, A. ebracteatus [40], S. involute, S. collinsae [41], and Smilax sp. [42].

At the protein level, we found a large difference in the production of IL-17A, IL-22, and IL-23 between the WCRtreated and untreated groups. While only TNF- $\alpha$ and IFN$\gamma$ treated $\mathrm{HaCaT}$ cells secreted large amounts of IL-17A, IL22 , and IL-23, $20 \mu \mathrm{M}$ of acitretin and $100 \mu \mathrm{g} / \mathrm{mL}$ of WCR significantly inhibited the TNF- $\alpha$ - and IFN- $\gamma$-stimulated IL$17 \mathrm{~A}, \mathrm{IL}-22$, and IL-23 secretion. Although $50 \mu \mathrm{g} / \mathrm{mL}$ of WCR did not show statistically significant reduction of IL-17A, IL-22, and IL-23 levels, it had the tendency to reduce the production of these inflammatory cytokines. Herein, the effect of WCR on inhibition of TNF- $\alpha$ - and IFN- $\gamma$-induced cytokine production highlighted a remarkable correlation between mRNA expression and protein secretion for IL17A, IL-22, and IL-23 biomarkers. A previous study has 
demonstrated that myeloid cell-produced IL-23 stimulates the differentiation of Th17 cells, leading to expansion and survival of these T cells [43]. Once Th17 cells are activated, they produce many mediators, including IL-17A and IL-22 which consequently induce proliferation of keratinocytes and other clinical symptoms of psoriasis [3, 44]. Recently, the novel biologic agents that specifically target IL-17A and the p40 subunit of IL-12 and IL-23 have been used effectively in the treatment of psoriasis $[45,46]$. Unfortunately, the limitations of these biologic drugs are ten-times higher direct costs than conventional systemic drugs [3], as well as other main concerns regarding the potential to increase infection and the risk of cancer from long-term chronic immunosuppression [6]. Thus, this study suggests that WCR, which is an affordable traditional medicine formulation, likely exerts antipsoriatic inflammation by inhibiting the expression of IL-17A, IL-22, and IL-23.

\section{Conclusion}

As part of our effort to develop an alternative treatment of antipsoriasis from natural products, the formulation of WCR crude extract at low concentrations was successfully proved to have potent anti-inflammatory effects, without having cytotoxicity or inducing cell cycle arrest, on the HaCaT cells. This indicates that WCR could be a promising candidate for further investigation and development for psoriasis therapy. To our knowledge, the current study is the first report to demonstrate the effect of WCR at the molecular level. This is a valuable information for developing reliable therapies. However, more accumulated evidence is needed to reveal all aspects of antipsoriatic properties of WCR to be ensured that WCR is effective and safe for use in psoriasis patients.

\section{Disclosure}

Mingkwan Na Takuathung is the first author. The authors have no special datasets in this article, but their data is available for reference.

\section{Conflicts of Interest}

The authors declare that they have no conflicts of interest.

\section{Authors' Contributions}

Mingkwan Na Takuathung conducted the experiments, data analyses and interpretation, and figures and manuscript preparation. Ariyaphong Wongnoppavich and Seewaboon Sireeratawong contributed to critical revisions. Ampai Panthong, Parirat Khonsung, Pornsiri Pitchakarn, and Natthakarn Chiranthanut revised the manuscript. Noppamas Soonthornchareonnon provided the Wannachawee Recipe. All authors have read and approved the final manuscript.

\section{Acknowledgments}

The authors would like to thank the Graduate School, Chiang Mai University, for providing academic and documentation support. They would also like to express their sincere gratitude to Chatchai Swaddichai, M.D., Ph.D., and Surasak Imiam, B.ATM, for providing the herbal plants of WCR and starting the use of WCR treatment in patients as well as initiating preclinical and clinical research of WCR. They would also like to thank Research Center of Pharmaceutical Nanotechnology, Chiang Mai University, Thailand. This study was supported in part by Agricultural Research Development Agency (Public Organization) (Grant no. CRP5705020550), Faculty of Medicine Graduate Student Scholarship, and Faculty of Medicine Research Fund, Chiang Mai University, Chiang Mai, Thailand (Grant no. 023-2560).

\section{References}

[1] M. P. Schön and W.-H. Boehncke, "Psoriasis," The New England Journal of Medicine, vol. 352, no. 18, pp. 1899-1912, 2005.

[2] L. Grine, L. Dejager, C. Libert, and R. E. Vandenbroucke, "An inflammatory triangle in psoriasis: TNF, type I IFNs and IL-17," Cytokine and Growth Factor Reviews, vol. 26, no. 1, pp. 25-33, 2015.

[3] W.-H. Boehncke and M. P. Schön, "Psoriasis," The Lancet, vol. 386, no. 9997, pp. 983-994, 2015.

[4] C. L. Langrish, Y. Chen, W. M. Blumenschein et al., "IL-23 drives a pathogenic $\mathrm{T}$ cell population that induces autoimmune inflammation," Journal of Experimental Medicine, vol. 201, no. 2, pp. 233-240, 2005.

[5] Y. Cai, C. Fleming, and J. Yan, "New insights of T cells in the pathogenesis of psoriasis," Cellular and Molecular Immunology, vol. 9, no. 4, pp. 302-309, 2012.

[6] M. A. Lowes, A. M. Bowcock, and J. G. Krueger, "Pathogenesis and therapy of psoriasis," Nature, vol. 445, no. 7130, pp. 866-873, 2007.

[7] A. Menter, N. J. Korman, C. A. Elmets et al., "Guidelines of care for the management of psoriasis and psoriatic arthritis. Section 4. Guidelines of care for the management and treatment of psoriasis with traditional systemic agents," Journal of the American Academy of Dermatology, vol. 61, no. 3, pp. 451-485, 2009.

[8] A. Menter, A. Gottlieb, S. R. Feldman et al., "Guidelines of care for the management of psoriasis and psoriatic arthritis. Section 1. Overview of psoriasis and guidelines of care for the treatment of psoriasis with biologics," Journal of the American Academy of Dermatology, vol. 58, no. 5, pp. 826-850, 2008.

[9] T. W. Corson and C. M. Crews, "Molecular understanding and modern application of traditional medicines: triumphs and trials," Cell, vol. 130, no. 5, pp. 769-774, 2007.

[10] C. Saelee, V. Thongrakard, and T. Tencomnao, "Effects of thai medicinal herb extracts with anti-psoriatic activity on the expression on NF- $\kappa \mathrm{b}$ signaling biomarkers in hacat keratinocytes," Molecules, vol. 16, no. 5, pp. 3908-3932, 2011.

[11] C. Swaddichai, V. Sukpaisarn, K. Chaichareonpong, P. Sanguantrap, and T. Limprapaipong, "Monitoring of Psoriasis Patients in Thai Traditional Medicine Clinic of Prapokklao Hospital," Journal of Thai Traditional \&amp; Alternative Medicine, vol. 9 , no. 1, p. 55.

[12] World Health Organization, WHO Guidelines for Assessing Quality of Herbal Medicines with Reference to Contaminants and Residues, Geneva, Switzerland, 2007.

[13] Ministry of Public Health, Thai Herbal Pharmacopoeia Volume IV. Department of Medical Sciences, 
[14] P. Skehan, R. Storeng, D. Scudiero et al., "New colorimetric cytotoxicity assay for anticancer-drug screening," Journal of the National Cancer Institute, vol. 82, no. 13, pp. 1107-1112, 1990.

[15] V. Vichai and K. Kirtikara, "Sulforhodamine B colorimetric assay for cytotoxicity screening," Nature Protocols, vol. 1, no. 3, pp. 1112-1116, 2006.

[16] C. Riccardi and I. C. Nicoletti, "Analysis of apoptosis by propidium iodide staining and flow cytometry," Nature Protocols, vol. 1, no. 3, pp. 1458-1461, 2006.

[17] C. Huang, C. Zheng, Y. Li, Y. Wang, A. Lu, and L. Yang, "Systems pharmacology in drug discovery and therapeutic insight for herbal medicines," Briefings in Bioinformatics, vol. 15, no. 5, pp. 710-733, 2014.

[18] C. Disayavanish and P. Disayavanish, "Introduction of the treatment method of Thai traditional medicine: Its validity and future perspectives," Psychiatry and Clinical Neurosciences, vol. 52, no. 1, pp. S334-S337, 1998.

[19] H. Tominaga, M. Ishiyama, F. Ohseto et al., "A water-soluble tetrazolium salt useful for colorimetric cell viability assay," Analytical Communications, vol. 36, no. 2, pp. 47-50, 1999.

[20] W.-P. Tse, C.-T. Che, K. Liu, and Z.-X. Lin, "Evaluation of the anti-proliferative properties of selected psoriasis-treating Chinese medicines on cultured HaCaT cells," Journal of Ethnopharmacology, vol. 108, no. 1, pp. 133-141, 2006.

[21] E. A. Olsen, “The pharmacology of methotrexate," Journal of the American Academy of Dermatology, vol. 25, no. 2 I, pp. 306-318, 1991.

[22] A. Yamauchi, T. Ichimiya, K. Inoue et al., "Cell-cycle-dependent pharmacology of methotrexate in HL-60," Journal of Pharmacological Sciences, vol. 99, no. 4, pp. 335-341, 2005.

[23] X.-Y. Lin, C.-D. He, T. Xiao et al., "Acitretin induces apoptosis through CD95 signalling pathway in human cutaneous squamous cell carcinoma cell line SCL-1," Journal of Cellular and Molecular Medicine, vol. 13, no. 9 A, pp. 2888-2898, 2009.

[24] R. Liwei, T. Weiming, T. Shengshun, Z. Ru, W. Wanjuan, and Z. Weihui, "Effects of ATRA, acitretin and tazarotene on growth and apoptosis of Tca8113 cells," Journal of Huazhong University of Science and Technology [Medical Sciences], vol. 25, no. 4, pp. 393-396, 2005.

[25] B. J. Nickoloff and F. O. Nestle, "Recent insights into the immunopathogenesis of psoriasis provide new therapeutic opportunities," Journal of Clinical Investigation, vol. 113, no. 12, pp. 1664-1675, 2004.

[26] J. Baliwag, D. H. Barnes, and A. Johnston, "Cytokines in psoriasis," Cytokine, vol. 73, no. 2, pp. 342-350, 2015.

[27] J. Cho, K. Lee, and C. Kim, "Curcumin attenuates the expression of IL- $1 \beta$, IL- 6 , and TNF- $\alpha$ as well as cyclin E in TNF- $\alpha$-treated $\mathrm{HaCaT}$ cells; NF- $\kappa \mathrm{B}$ and MAPKs as potential upstream targets," International Journal of Molecular Medicine, 2007.

[28] S.-J. Jeong, H.-S. Lim, C.-S. Seo et al., "Anti-inflammatory actions of herbal formula Gyejibokryeong-hwan regulated by inhibiting chemokine production and STAT1 activation in HaCaT cells," Biological \& Pharmaceutical Bulletin, vol. 38, no. 3, pp. 425-434, 2015.

[29] S.-J. Jeong, H.-S. Lim, C.-S. Seo et al., “Traditional herbal formula Jakyakgamcho-tang (Paeonia lactiflora and Glycyrrhiza uralensis) impairs inflammatory chemokine production by inhibiting activation of STAT1 and NF- $\kappa$ B in HaCaT cells," Phytomedicine, vol. 22, no. 2, pp. 326-332, 2015.
[30] K. Asadullah, W. Sterry, K. Stephanek et al., "IL-10 is a key cytokine in psoriasis," The Journal of Clinical Investigation, vol. 101, no. 4, pp. 783-794, 1998.

[31] A. K. Chudiwal, D. P. Jain, and R. S. Somani, "Alpinia galanga Willd.- An overview on phyto-pharmacological properties," Indian Journal of Natural Products and Resources, vol. 1, no. 2, pp. 143-149, 2010.

[32] T.-T. Di, Z.-T. Ruan, J.-X. Zhao et al., "Astilbin inhibits Th17 cell differentiation and ameliorates imiquimod-induced psoriasislike skin lesions in BALB/c mice via Jak3/Stat3 signaling pathway," International Immunopharmacology, vol. 32, pp. 32$38,2016$.

[33] C.-L. Lu, W. Zhu, D.-M. Wang et al., "Inhibitory effects of chemical compounds isolated from the rhizome of smilax glabra on nitric oxide and tumor necrosis factor- $\alpha$ production in lipopolysaccharide-induced RAW264.7 cell," Evidence-based Complementary and Alternative Medicine, vol. 2015, Article ID 602425, 2015.

[34] C.-L. Lu, Y.-F. Zhu, M.-M. Hu et al., "Optimization of astilbin extraction from the rhizome of smilax glabra, and evaluation of its anti-inflammatory effect and probable underlying mechanism in lipopolysaccharide-induced raw264.7 macrophages," Molecules, vol. 20, no. 1, pp. 625-644, 2015.

[35] M. Fei, X. Wu, and Q. Xu, "Astilbin inhibits contact hypersensitivity through negative cytokine regulation distinct from cyclosporin A," Journal of Allergy and Clinical Immunology, vol. 116, no. 6, pp. 1350-1356, 2005.

[36] S. Zou, X. Shen, Y. Tang, Z. Fu, Q. Zheng, and Q. Wang, "Astilbin suppresses acute heart allograft rejection by inhibiting maturation and function of dendritic cells in mice," Transplantation Proceedings, vol. 42, no. 9, pp. 3798-3802, 2010.

[37] W. Reanmongkol, A. Itharat, and P. Bouking, "Evaluation of the anti-inflammatory, antinociceptive and antipyretic activities of the extracts from Smilax corbularia Kunth rhizomes in mice and rats (in vivo)," Songklanakarin Journal of Science and Technology, vol. 29, no. 1, pp. 59-67, 2007.

[38] S. Bukke, P. S. Raghu, G. Sailaja, and T. R. Kedam, “The study on morphological, phytochemical and pharmacological aspects of Rhinacanthus nasutus. (L) kurz (A review)," Journal of Applied Pharmaceutical Science, vol. 1, no. 8, pp. 26-32, 2011.

[39] A. Gotoh, T. Sakaeda, T. Kimura et al., "Antiproliferative activity of Rhinacanthus nasutus (L.) KURZ extracts and the active moiety, rhinacanthin C," Biological and Pharmaceutical Bulletin, vol. 27, no. 7, pp. 1070-1074, 2004.

[40] D. Singh and V. Aeri, "Phytochemical and pharmacological potential of Acanthus ilicifolius," Journal of Pharmacy and Bioallied Sciences, vol. 5, no. 1, pp. 17-20, 2013.

[41] B. Brem, C. Seger, T. Pacher et al., "Antioxidant dehydrotocopherols as a new chemical character of Stemona species," Phytochemistry, vol. 65, no. 19, pp. 2719-2729, 2004.

[42] A. Vijayalakshmi, V. Ravichandiran, M. Velraj, S. Nirmala, and S. Jayakumari, "Screening of flavonoid "quercetin" from the rhizome of Smilax china Linn. for anti-psoriatic activity," Asian Pacific Journal of Tropical Biomedicine, vol. 2, no. 4, pp. 269-275, 2012.

[43] E. Bettelli, M. Oukka, and V. K. Kuchroo, " $\mathrm{T}_{H}-17$ cells in the circle of immunity and autoimmunity," Nature Immunology, vol. 8, no. 4, pp. 345-350, 2007.

[44] M. P. Schön, "The plot thickens while the scope broadens: A holistic view on IL-17 in psoriasis and other inflammatory disorders," Experimental Dermatology, vol. 23, no. 11, pp. 804806, 2014. 
[45] R. G. Langley, B. E. Elewski, M. Lebwohl et al., "Secukinumab in plaque psoriasis-results of two phase 3 trials," The New England Journal of Medicine, vol. 371, no. 4, pp. 326-338, 2014.

[46] A. Nast, A. Jacobs, S. Rosumeck, and R. N. Werner, "Efficacy and Safety of Systemic Long-Term Treatments for Moderateto-Severe Psoriasis: A Systematic Review and Meta-Analysis," Journal of Investigative Dermatology, vol. 135, no. 11, pp. 26412648, 2015. 


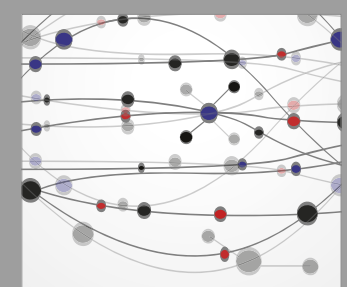

The Scientific World Journal
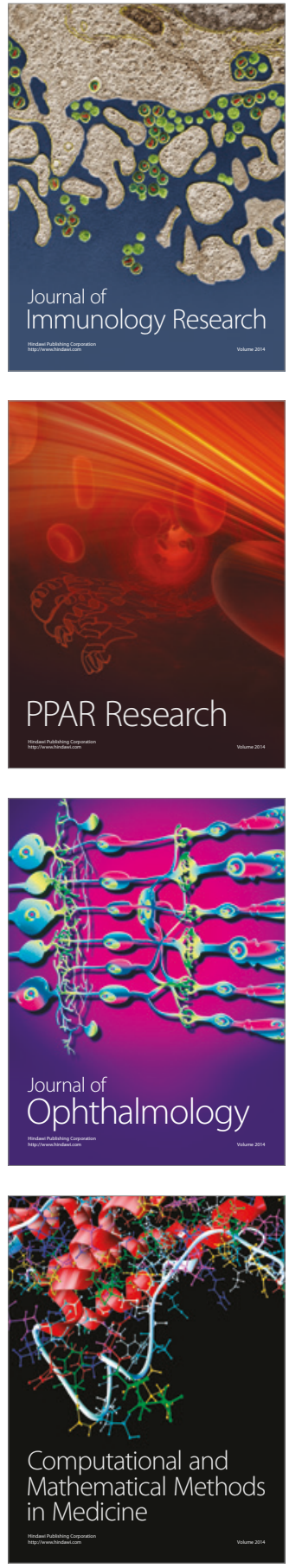

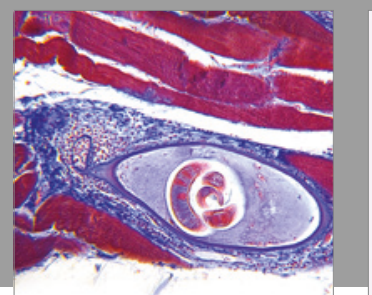

Gastroenterology Research and Practice
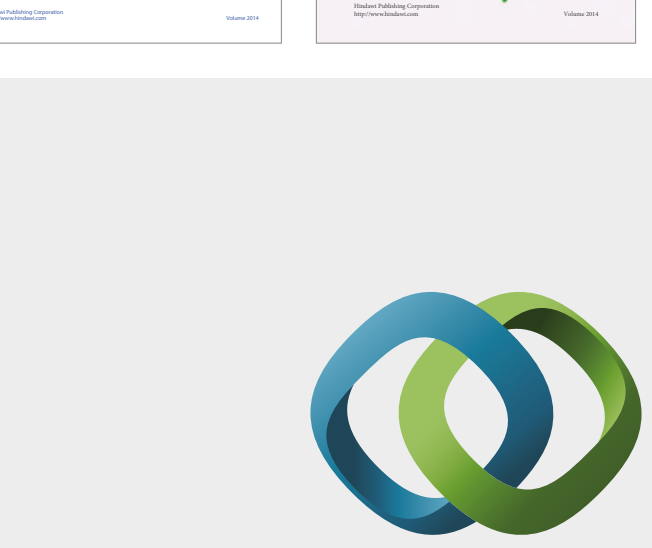

\section{Hindawi}

Submit your manuscripts at

https://www.hindawi.com
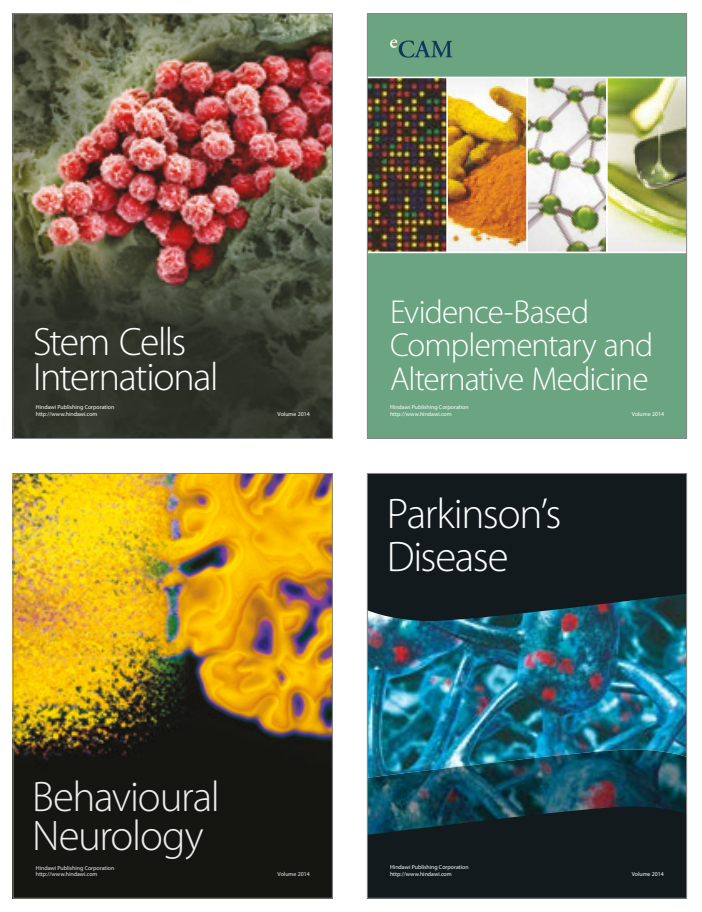
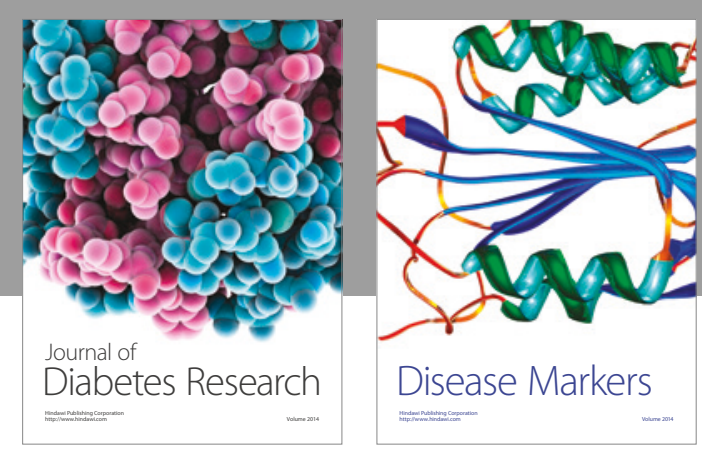

Disease Markers
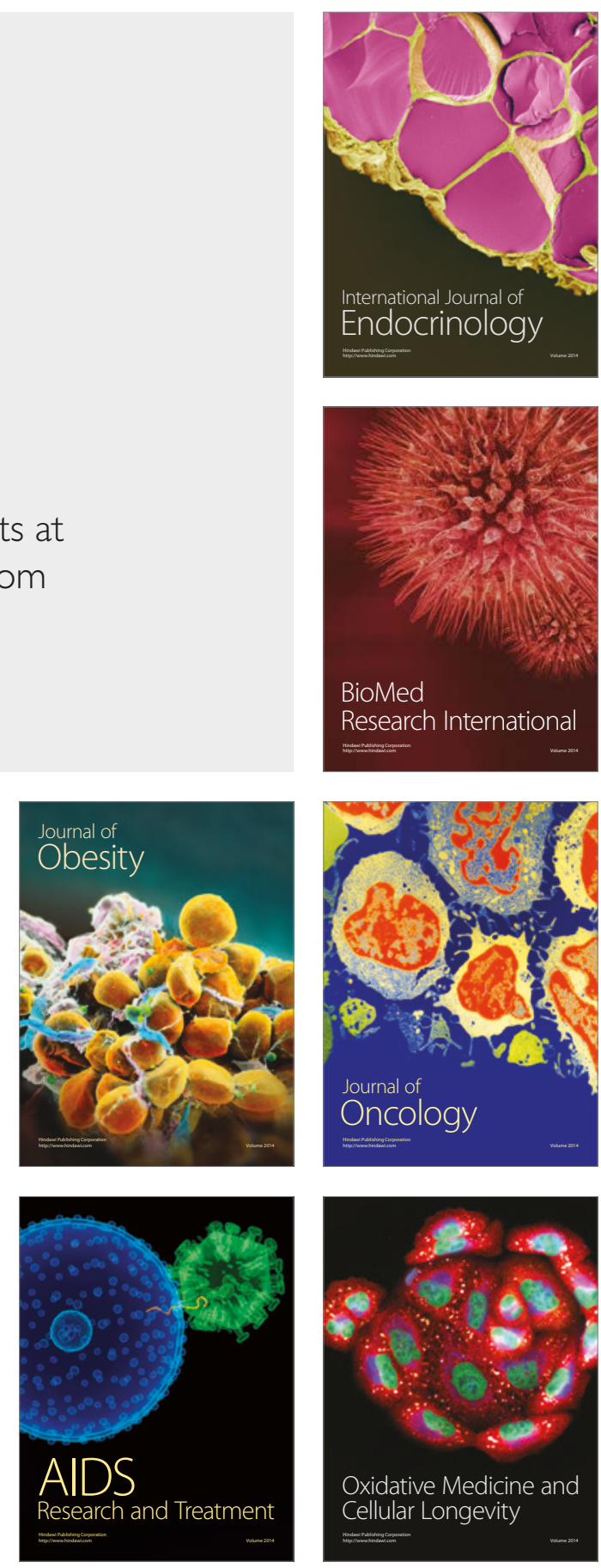